\title{
評価グリッド法を用いた俯瞰眺望景観に対する心理的評価の傾向分析 AN ANALYSIS OF PSYCHOLOGICAL EVALUATION OF VIEWS FROM HIGH POINTS BY EVALUATION GRID METHOD (EGM)
}

\author{
土田義郎*1，川浐 寧史*2，下川雄一*2 \\ Yoshio TSUCHIDA, Yasushi KAWASAKI and Yuichi SHIMOKAWA
}

\begin{abstract}
This article is a fundamental study of the favorability of the townscape. Especially, the study aimed to clarify what kind of elements are most important and what kind of psychological impressions occur when subjects take in views from high points. Personal cognitive constructs of desirability were determined using the Evaluation Grid Method (EGM). Seven kinds of bird's-eye views were used, such as a townscape in which a rice field remains, a traditional residential section with tiled rooftops, and so on. These pictures were printed in A4 size with color and without color by laser printer. The results of this research showed that various imaginations are awakened by color images. From visual clues about the degree of modernity such as an electric wire, a steel tower, a bridge or a road, subjects understood the state of the natural environment of the town, ease of living and general atmosphere. Also, it was shown that factors such as the greenness of the plants, the newness (oldness) of buildings and the layout of buildings were key elements for estimation. The lucidity of scene structure and natural abundance participate in the likability of a bird's-eye view scene. It was shown that a mixture of traditional houses and new houses, agricultural land and residential/commercial establishments create a confused impression without a feeling of unification.
\end{abstract}

Keywords : View, Favorability, Viewpoint, Color, Evaluation grid method 景観, 好ましさ, 視点, 色彩, 評価グリッド法

1. はじめに

\section{1-1. 研究の背景}

都市景観の眺望としては、街路からの水平もしくはやや仰角のあ る景観が一般的である。その一方で、各地に見られる夜景スポット や風景の展望点のように、俯瞰した景観を楽しむことのできる場所 も数多くある。広がりを持った都市の俯瞰景観も、地域の景観資源 の一つとして重要なものである。しかしながらこのような高所から の景観については、視覚的な領域が広範囲に及ぶ。1つの街路をコ ントロールするより格段に広い領域における建築物や工作物、植生 といったものを扱わなければならない。そのため、景観全体をコン トロール寸ることが難しく、研究も限られたものであった。

金沢市は伝統的文化に対する基本的な政策に基づき、都市景観に 対しても積極的な施策 1)をとっている。これらもその多くは水平以 上の仰角のある景観についてである。重要伝統的建造物群として指 定されている東山茶屋街などを一望できる地点である卯辰山や、金 沢城の一部からの俯瞰景観にかかわる規制は存在していない。伝統 的な都市の美しさを点でなく、面として保全するためにはこういっ た伝統的都市地域の俯瞰景観についての対策が必要である。将来的
に何らかのコントロールが必要になってくると考えられる。街路景 観よりも可視領域が広い俯瞰景観では、どのような着眼点が必要で あるのか。こういった点について客観的に明らかにしておくことは、 都市的な規模でのまちづくりに必要なことである。

\section{1-2. 研究の目的}

本研究では、都市景観の好ましさに対する評価のための基礎的な 定性調查を実施する。特に全体的な景観の中で、俯瞰景観において はどのような要素が着目され、どのような主観的な心理評価と結び ついているのかを明確にする。パーソナル・コンストラクト理論に 基づき、景観の評価構造の一部である「俯瞰景観に対する好ましさ の評価構造」を、評価グリッド法を援用して明らかにすることを目 的としている。

\section{1-3. 既往研究との位置づけ}

既に筆者ら ${ }^{1)}$ は同一地点の俯瞰景観に対して評価実験を行ってい る。文献 1 は対象と寸る景観のグレースケール画像を用い、SD 法 によって評価している。また、全体画像に対して部分を切り出した 画像の評価から、全体と部分の関連について画像解析を交えて考察 している。基本的な問題意識は共通しており、ここでは特に前述の
*1 金沢工業大学環境・建築学部建築系 教授・博士 (工学)

*2 金沢工業大学環境・建築学部建築系 准教授・博士 (工学)
Prof., College of Environmental Engineering and Architecture, Dept. of Architecture, Environmental Design, Kanazawa Institute of Technology, Dr. Eng.

Assoc. Prof., College of Environmental Engineering and Architecture, Dept. of Architecture, Environmental Design, Kanazawa Institute of Technology, Dr. Eng. 
ような評価構造の解明に特化した検討を行うものである。本研究で も同一の画像を用いて実験を行っている。特にフルカラー画像とグ レースケール画像を対照することで、景観の認識に与える色彩の影 響についても明らかにすることを意図している。

評価グリッド法は開発当初こそ建築物のファサードの評価に適用

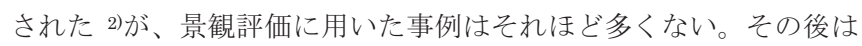
景観よりも施設全体や工業製品といった物への応用が多く、また視 覚的な景観以外にも適用の幅を広げてきている。例えば、聴覚的な 事象のようにその場の過渡的な環境要素に対しては、知覚された聴 覚事象を記録することで、音環境の評価構造を明らかにできる ${ }^{3)}$ 。

奥ら 4)は、B4 サイズのカラープリンタ出力を用いて、嵐山らしい 地域景観の構造はどのようなものかを探索した。3 個組法によって 景観の印象の全体的な評価軸を求め、さらに評価グリッド法を援用 し、ラダーリングによって階層的評価構造を示している。

松本ら5は、農地の景観に対する心理的な構造を分析するために、 評価グリッド法によって評価構造を推定し、要因の分類の妥当性を SD 法によって検証している。

長岡ら ${ }^{6)}$ は、評価項目の抽出のために、屋上緑化の状態を近接し た位置から撮影したビデオ映像を用いて評価グリッド法を行ってい る。景観全体の評価ではなく、SD 法による評価のための項目抽出と いう補助的な使用である。

本研究の関連領域としては、眺望景に関するもの、景観の印象評 価に関するものがある。

眺望に関しては、遠望と俯瞰という枠組みに大別できる。まず遠 望に関しては、奥行きによる建築や景観要素の識別をテーマとした 上野・高橋他による先駆的成果 7,8)をはじめとし、視知覚に基づいた 識別距離の推定9など数多くの研究報告がある。俯瞰景については、 (1)街や自然などが一望できる眺望景観（眺望地点も含む）そのもの を評価対象におくものと、(2)高層住宅からの眺望といった居住環境 の価值として眺望を考察とするものがある。

(1)については、例えば篠原・樋口による俯角と港町の見やすさに 関寸る研究 10)を先駆的成果とし、夜景眺望の構図と印象を分析した もの 11)などがある。(2)いいては居住者・非居住者を実験対象に、 眺望の構成・眺望画像の特徴量・印象評価などの分析手法を適宜組 み合わせた研究が進められている。例えばクフィル他による人工島 における高層住戸からの眺望評価 ${ }^{12)}$ 、横田・村上 他による住民撮 影眺望景に対する選好性の一連の研究 ${ }^{13}$ 16)などがある。クフィル他 12) は、大阪湾人工島の高層マンションの位置と高さレベル、眺望景 写真の景観要素の距離と面積割合、住民の意識調查から眺望性の評 価を行っている。また、横田・村上他は非住民の被験者に対寸る水 際高層マンションの各階からの眺めの選好性とイメージ評価 ${ }^{13)}$ 、水 際の眺望景を対象とした住民の選好性と画像特徴量 ${ }^{14)}$ 、非住民被験 者の着目範囲 - 要素や選好性と画像特徴量 ${ }^{15}$ )、非住民による眺望景 の心理評価 ${ }^{16)}$ など検討する一連の研究を実施している。この他には、 居住空間の眺望評価を不動産価值の視点で分析した研究事例 17) も ある。

既往文献を概観すると同じ眺望景観といっても評価の立場には相 違がある。一つは「街や自然などが一望できる眺望景観（眺望地点 も含む）そのものを評価対象におく」という立場であり、もう一つ は、高層住宅からの眺望といった居住環境の価值として眺望を考察
する」という立場である。本研究は前者の立場であり、卯辰山と県 庁展望ロビーといった金沢でも数少ない眺望地点と眺望対象の関係 を分析したものであり、特にこの 2 地点は旧市街地と新市街地とい う眺望景観の地域対比も含まれているという研究意図がある。

\section{2. 実験方法}

本研究では評価の要因となる個人の評価構造を同定することが重 要であるため、ここでは評価グリッド法によるインタビュー調査を 実施した。この方法を用いることで、被験者自身の言葉による評価 が得られ、心理的な評価構造を階層的にとらえることが可能となる。 人間の意識の質的な側面をとらえる事がその狙いである。その代わ り、程度を問うような量的な判断は行うことができない。あらかじ め設定した言葉によって、1元的かつ量的な評価を行う SD法とは、 この点が大きく異なる。

\section{2-1. 被験者}

インタビューは、20 代の男子学生 8名（以下「青年群」）と 30〜 40 代の男性 2 名、女性 1 名（以下「壮年群」）を被験者として行っ た。青年群の被験者は 3 年以上、壮年群の被験者はそれ以上石川県 に居住しているが、日常的に対象地点の景観を目にしているわけで はない。

\section{2-2. 評価対象（エレメント）}

景観評価の対象地点は、文献 2 でのデータと共通である。使用し た画像も同じものを使用している。具体的には金沢市内の代表的な 俯瞰景観が望める場所として、卯辰山山腹と 2003 年に完成した石 川県庁舎 19 階展望ロビーの 2 ヶ所を選定している（表 1 )。

実験に用いた画像を図 1 に示す。画像には識別の記号として、卯 辰山には U、石川県庁には $\mathrm{K}$ を付している。

卯辰山からの眺望を概観すると、目前を左右に横切って浅野川が 流れ、茶屋街を中心とした木造家屋や、金沢城の石垣・植栽が眺め られる。正面には金沢城の石垣も見ることができる。浅野川の上流 側、中流付近、下流側の三方の俯瞰景観をデジタル一眼レフカメラ (本体 : CANNON EOS D30、レンズ : SIGMA 15-30mm F3.54.5 EX DG ASPHERICAL、レンズ焦点距離 : $30 \mathrm{~mm}$ 、絞り : F3.5、 画素数 : $2160 \times 1440$ pixel）によって撮影した。

石川県庁舎の最上階展望ロビーからの眺望を概観すると、金沢駅 からの片側 3 車線の幹線道路が延び、金沢港に続く。周囲は大規模 商業建築が徐々に建ち始めているが、方位によっては農地もまだ多 く残る。展望台は東西南北の四方を望むことができ、これも卯辰山 と同じ機材を用いて撮影した。この地域は近年の都市計画により開 発途上の場所である。

表 1 俯瞰景観の展望場所

\begin{tabular}{|l|l|}
\hline 展望地点 & 主な景観構成 \\
\hline 卯辰山（標高 $141 \mathrm{~m} ）$ & 伝統的な建築群である東山茶屋街や \\
山腹にある寶泉寺境内 & 主計町茶屋街、金沢城、浅野川、そ \\
(市街地との標高差約 $40 \mathrm{~m})$ & の他住宅・マンション群 \\
\hline 石川県庁舎（軒高 $85.6 \mathrm{~m})$ & 金沢駅から金沢港に続く片側 3 車線 \\
最上階展望ロビー & の幹線道路、大規模商業建築、農地、 \\
(市街との標高差約 $75 \mathrm{~m})$ & 港（日本海）、住宅群 \\
\hline
\end{tabular}




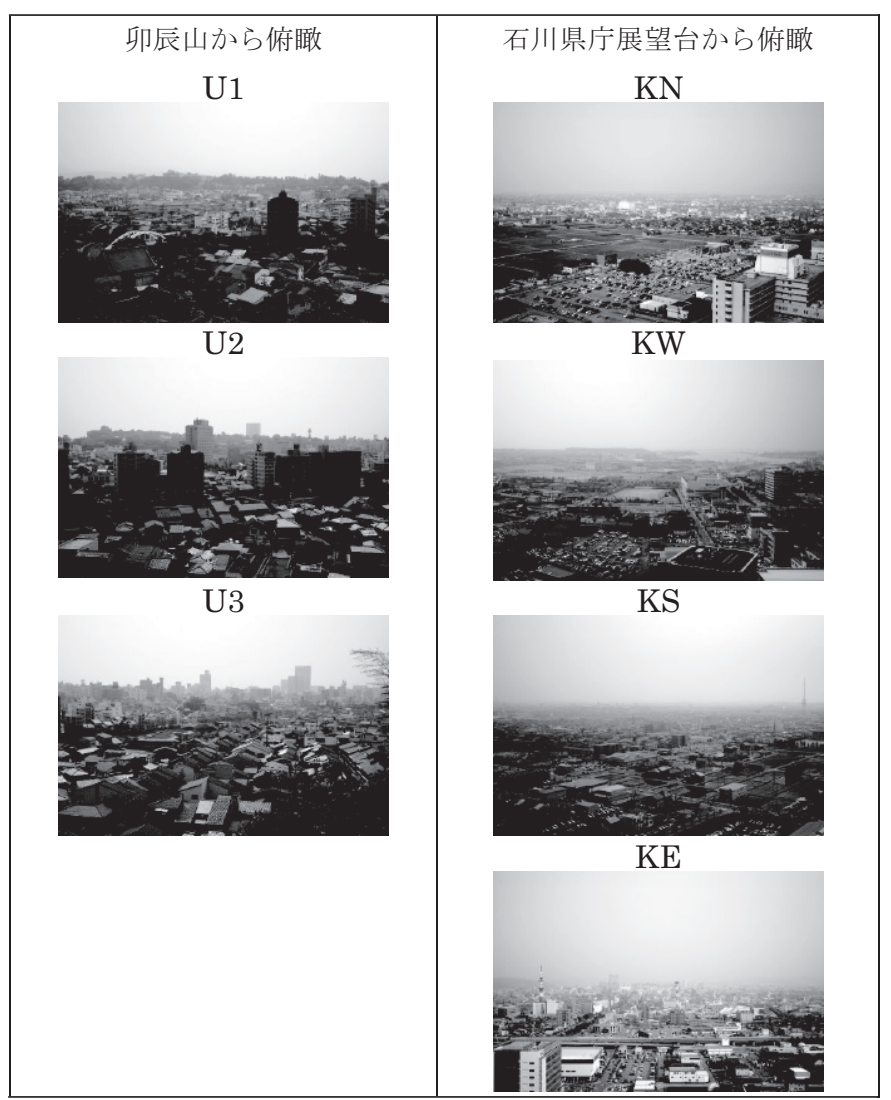

図 1 実験に用いた画像

(撮影日時: 2006 年 6 月 1 日、午後 2 3 時、天候：晴れ)

上記 7 種の景観画像は、カラー・レーザー・プリンタ (EPSON LP - A500F）を用いて A4 サイズ上質紙に、印刷可能範囲の上限の大 きさ（縦 19.1×横 $28.6 \mathrm{~mm}$ ）に印刷した。それぞれの画像はグレー スケールで印刷したものと、フルカラーで印刷したものをエレメン トとして用意した。印刷に当たって、ドライバで色彩の調整を行え るが、今回印刷状況を目視によって確認したところ、発色状態は良 好であり、特に調整は行わなかった。

展望地点がどこであるかについては被験者に開示していないが、 実験後のヒアリングによると、ある程度どの辺りであるかについて はわかったようである。対象地域は住民には馿染み深い場所であり、 数年以上の居住歷があれば推定できるようである。しかし、展望地 点には来訪経験が無い、あるいはほとんど無く、景観状況を詳細に 記憶してはいない。

\section{2-3. 実験手順}

実験 1 としては、色彩の影響を受けないようにグレースケールの 画像を用いて一連のインタビューを実施した。これにより、景観要 素の形状とその状態から喚起されるイメージによる評価となること を意図している。

その後、 1 週間以上時間を置いて、実験 2 としてカラーの画像を エレメントとしたインタビューを行った。色彩情報によってイメー ジがどのように変容し、評価に影響するかを検証することを意図し ている。

被験者は、まずエレメントとしての画像を景観の好ましさの点か ら 5 段階にランク付けした。最も好ましくないと評価されたランク の対象群と、その上位にランク付けされた対象群について、個々の
エレメント全てを対とした比較を行い、異なるランクと評価された 理由をたずねた。次いで 1 ランクずつ上の対象群についても同様に 比較した。これらの手続きで得られた理由をオリジナル評価として いる。

評価グリッド法にはいくつかバリエーションがあり、群同士を比 較して相違点を抽出する方法もある。ここでは、エレメントの数が 少ないため、できる限り比較回数を多くすることを意図して、群内 の各エレメントを総当りで比較する。この方法は筆者らの開発した 評価グリッド法支援ツール「EGM assist」8)の手順となっている。

次いで、オリジナル評価に対するラダーリングを行う。すなわち、 評価の原因となる具体的な環境・空間条件を聞き出すラダー・ダウ ンと、その評価がさらにどのような根源的心理・印象と連なるのか を聞き出すラダー・アップを実施する。これらを繰り返すことで好 ましさに関わる評価構造を個人ごとに同定することができる。

\section{3. 実験結果}

評価グリッド法によって得られるネットワーク図は、多様な言葉 で複雑に連結している。これらをすべての被験者について1枚にま とめたとしても、その結果は膨大なものになり、そこから考察結果 を示すのはわかりにくい。また、従来評価グリッド法ではネットワ ークによって得られる構造が主要な結果として扱われていたが、各 エレメントがどのようなランクに評価されたのかという情報も有用 なはずである。そのためここではネットワーク図だけを示すのでは なく、まず全体的な評価の言葉の構成とエレメントに対するランク 付けの結果の傾向を示す。その後、どのような景観要素がどのよう な評価と関連しているのかを考察する。

\section{3-1. 全体的な認知構造について}

はじめに、オリジナル評価とラダーリングの結果得られた評価語 の代表的なものを表 2 に示す。右側はラダー・アップ、左側はラダ ー・ダウン側になる。これは、厳密なものではなく、評価の言葉の 意味として分けたものである。表の上部に示したような、「具体的な 景観や環境の要素」であるか、「印象や想定される利点」であるか、

表 2 評価の言葉の概要

\begin{tabular}{|c|c|c|}
\hline $\begin{array}{c}\text { 一般的 } \\
\text { 印象や価值 }\end{array}$ & $\begin{array}{c}\text { 個別の印象や } \\
\text { 想定される利点 }\end{array}$ & $\begin{array}{c}\text { 具体的な景観や } \\
\text { 環境の要素 }\end{array}$ \\
\hline $\begin{array}{l}\text { 落ち着く } \\
\text { 癒される } \\
\text { 和む } \\
\text { あたたかい } \\
\text { 気持ちがいい } \\
\text { 懐かしい } \\
\text { 心が安らぐ } \\
\text { 清清しい } \\
\text { 明るい }\end{array}$ & $\begin{array}{l}\text { 自然を感じる } \\
\text { 開放感や清潔感を感じる } \\
\text { 空気がきれい } \\
\text { 静か } \\
\text { 環境に配慮している } \\
\text { 行きたくなる } \\
\text { まちづくりがされている } \\
\text { 住みたい } \\
\text { まちの霉囲気がいい } \\
\text { 子どもが活発に遊べそう } \\
\text { 活気がある } \\
\text { 治安がいい } \\
\text { 暮らしやすい } \\
\text { 生活に便利 } \\
\text { ゆりを感じる } \\
\text { 将来性がある }\end{array}$ & $\begin{array}{l}\text { 緑がある } \\
\text { ビルが少ない } \\
\text { 伝統的な建物 } \\
\text { 建物の配列がきれい } \\
\text { 高・低層建築のバランス } \\
\text { ランドマーク的な建物 } \\
\text { 橋が見える } \\
\text { 近代的な建物 } \\
\text { 建物の色が鮮やか } \\
\text { 建物に凹凸がある } \\
\text { 大通りに面している } \\
\text { 国道が見える } \\
\text { 車が少ない } \\
\text { 田んぼがある景観(土) } \\
\text { 空地がある(一) } \\
\text { 駐車場がある(一) } \\
\text { 電線が見える(一) } \\
\text { 鉄塔、タワーが見える }(-)\end{array}$ \\
\hline 上位評価 & \multicolumn{2}{|c|}{$\leftarrow \quad($ ラダーリング $) \rightarrow$ 下位評価 } \\
\hline
\end{tabular}

(一)は否定的要素、 $( \pm)$ は被験者によって肯定・否定が分かれる要素 
特定の知覚や具体的な対象によらない一般的な心理としての「非特 異的評価」であるかを筆者が判定・分類した。これはラダーリング の状況そのものを現しているのではない。実際にはオリジナル評価 時に具体的な景観要素が指摘されたり、非特異的な評価語が現れた りした場合もある。

次に、被験者個人ごとの評価語の数を比較した。グレースケール とカラーとを散布図で示したものが図 2 である。対角線上にプロッ トがある場合に等しい数であることを示し、対角線より下になると カラーの場合の評価語が多いことを示している。

グレースケールでは平均で約 34 語、カラーでは平均で約 42 語の 評価語が現れることがわかる。被験者 7 と 9 を除いてグレースケー ルによる評価語の数より、カラーによる評価語の数の方が多く、平 均值で 7.3 個程度の差が見られる。この差は危険率 $5 \%$ で統計的に 有意であった。グレースケールによる評価の際に、色のイメージか ら感じられる要因が入るのを防ぐためにグレースケールを先に実施 し、期間を置いて後からカラーによる実験を行った。そのため、カ ラーの方では慣れが生じていたことも考えられるが、色彩条件など の着目要素が多くなったために多様な評価語が現れやすくなったと も考えられる。相関係数は 0.46 とやや正の相関が見られる程度であ った。

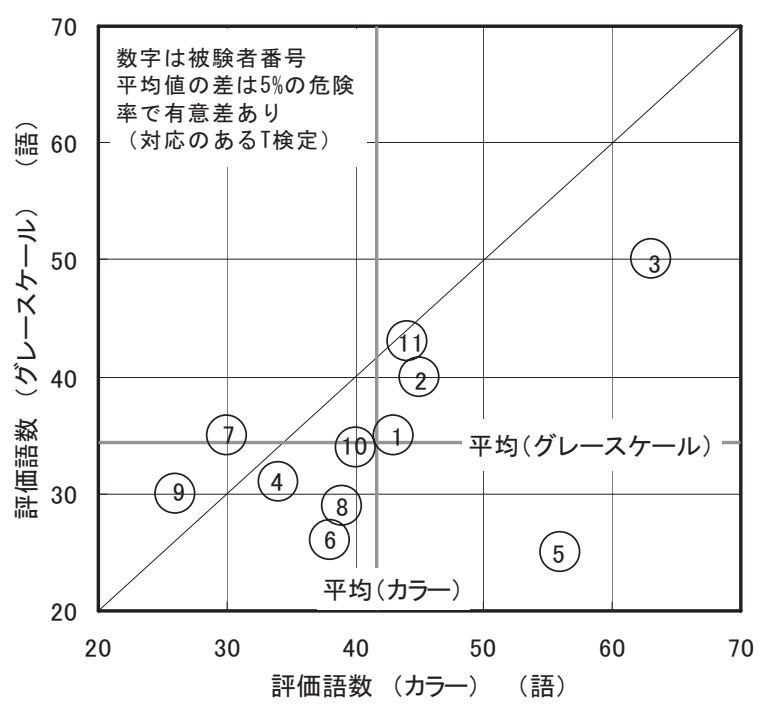

図 2 被験者の評価語数の分布

(1 8: 青年群、9 $11:$ 壮年群)

\section{3-2. 景観要素と評価の関わり}

景観要素と評価の関連をラダーリング結果から推定する。まず、 具体的な景観や環境の要素（表 2 右列）を見ると、樹林などの緑、 建物の新しさ(古さ)、建物の並び方など、まちなみの状況がある。 特に景観の評価を悪化させる要因としては空地、駐車場などが挙げ られている。これは空間的な配置の規則性を損なうためではないか と考えられる。また、電線や鉄塔も好ましい物としてとらえられて いない。まちなみ本来の構図を阻害している物と考えられる。反対 に景観を好ましく感じさせる要素としては、伝統的な建造物、ラン ドマーク的な建物、近代的な建物といった建築物の状況がある。大 通り、国道、橋といったものも好ましい要素となっているのは、道
路が都市の構図をはっきりさせる効果を有しているためではないか と考えられる。緑や田園も好ましい物としてとらえられる場合が多 いが、田園は負の効果を持つ場合もある。これは都市的なものに憧 れを持つ被験者にとっては、田に「田舎くささ」という印象を抱く ためではないかと考えられる。

その場所の印象としては、自然環境の状態、暮らしやすさ（治安、 利便性、将来性など）、まちの全体的雾囲気（開放感、清潔感、落ち 着き、静けさなど）を感じ取っている。電線・鉄塔・橋・道など町 の基幹的構築物の状況を見ることでこれらの印象が生じている物と 考えられる。

\section{3-3. 景観の好ましさの評価}

5 段階のランク付けの值を、一覧表の形にまとめると表 3 のよう になる。これを属性に基づいてエレメントごとに平均した（図 3）。 平均の差については対応のある $\mathrm{T}$ 検定により有意確率 $\mathrm{p}$ （両側）を 求めた。概放似かよった傾向であるが、 KN の評価に有意な差が見 られる。他にも有意ではないが多少評価の異なる点があることから、 色彩情報の有無による影響が示唆される。

年齢によっても景観の好みに相違が生じる可能性がある。世代別 に好ましさに対する評価の平均值を図 4 に示す。平均の差について は群ごとのケース数が異なるため、等分散を仮定しない $\mathrm{T}$ 検定を行 い有意確率 $\mathrm{p}$ （両側）を求めた。世代によらずほぼ同様の傾向を示 しており、評価の違いも有意差は見られなった。しかし評価のラン ク自体は個人差が非常に大きかった。エレメントによっては、ラン クが 1 から 5 まで幅広く分布していた。

\section{4. 考察}

\section{1 エレメントに対するランク付けの傾向から}

ランクの付け方には表 3 に示すように、色彩の有無による差や、 年齢とは関連の無い個人差が見られた。そのため被験者をクラスタ 一分析によって分類し、グループごとの特徴について考察する。

図 5 はエレメントの景観の好ましさをランク評価した值によるク ラスター分析（ウォード法）の結果である。分析ソフトにはシェア ウエアの「Let's stat!」19)を用いている。

まず、全体が 1 つのクラスターに結合するまでの距離を見るとカ ラーは約 90、グレースケールでは約 72 であり、カラーの方が全体 的に距離が遠くなっているといえる。すなわち、被験者による全体 的な印象の幅が大きくなっていることを示している。カラーの方が、 より多様な要素への着目点が現れることでイメージの幅が広がり、 このような結果が得られたのではないかと推測される。これは 3.1 で示した、評価語の数がカラーの方が多くなるという結果と整合す る。

次に、結合グループについて比較する。ユークリッド平方距離 35 近辺で分割してみると、カラーもグレースケールも 3 つのグループ に分けることができる。カラーでは「 $1,4,7,8,9 」 、 「 2,5,11 」 、 「 3,6,10 」$ に分かれ、グレースケールでは「1,4,7,8,11」、「2,3,5,6,9」、「10」に 分かれる。

被験者「3,5,6,7,9,11」の被験者は、表 3 の RMS 值（グレースケ ールとカラーの評価の差の自乗平均の平方根）を見ると、色の有無 によって評価の変化が 1 ランクを超えていることがわかる。そのた めこれらの被験者はグレースケールとカラーで異なるクラスターに 
分かれたと考えられる。

また、エレメント側に着目すると、表 3 よりほとんどのエレメン トで 1 ランクほどの変動が見られることが分る。KW のみ RMS 值 が 1 を下回っている。KW は U1 とともに評価の高いエレメントで あったが、評価傾向が色の有無によって恋わりにくい物であったと

表3＼cjkstart景観の好ましさランク（好ましいものほど数值大）

\begin{tabular}{|c|c|c|c|c|c|c|c|c|c|c|c|c|c|c|c|c|}
\hline \multirow{2}{*}{\multicolumn{2}{|c|}{ 被験者 }} & \multicolumn{2}{|c|}{$\mathrm{U} 1$} & \multicolumn{2}{|c|}{$\mathrm{U} 2$} & \multicolumn{2}{|c|}{ U3 } & \multicolumn{2}{|c|}{$\mathrm{KN}$} & \multicolumn{2}{|c|}{$\mathrm{KW}$} & \multicolumn{2}{|c|}{$\mathrm{KS}$} & \multicolumn{2}{|c|}{$\mathrm{KE}$} & \multirow[b]{2}{*}{ RMS } \\
\hline & & $\mathrm{G}$ & C & $\mathrm{G}$ & $\mathrm{C}$ & G & $\mathrm{C}$ & $\mathrm{G}$ & C & $\mathrm{G}$ & $\mathrm{C}$ & $\mathrm{G}$ & C & $\mathrm{G}$ & C & \\
\hline \multirow{8}{*}{$\begin{array}{l}\text { 青 } \\
\text { 年 } \\
\text { 群 }\end{array}$} & 1 & 5 & 5 & 4 & 3 & 4 & 3 & 2 & 2 & 3 & 4 & 1 & 1 & 3 & 2 & 0.57 \\
\hline & 2 & 3 & 2 & 3 & 2 & 2 & 1 & 5 & 5 & 4 & 4 & 5 & 5 & 1 & 3 & 0.71 \\
\hline & 3 & 5 & 4 & 4 & 1 & 2 & 1 & 3 & 2 & 4 & 5 & 3 & 2 & 1 & 3 & 1.43 \\
\hline & 4 & 4 & 5 & 5 & 4 & 3 & 2 & 1 & 3 & 2 & 2 & 3 & 1 & 3 & 3 & 1.00 \\
\hline & 5 & 4 & 1 & 3 & 4 & 2 & 3 & 2 & 5 & 5 & 5 & 4 & 1 & 1 & 2 & 1.71 \\
\hline & 6 & 5 & 4 & 4 & 1 & 3 & 3 & 2 & 3 & 4 & 5 & 3 & 2 & 1 & 3 & 1.29 \\
\hline & 7 & 5 & 4 & 4 & 2 & 2 & 5 & 1 & 1 & 3 & 3 & 1 & 2 & 4 & 3 & 1.14 \\
\hline & 8 & 4 & 5 & 2 & 3 & 5 & 4 & 1 & 2 & 3 & 2 & 1 & 1 & 2 & 1 & 0.86 \\
\hline 壮 & 9 & 5 & 5 & 3 & 5 & 2 & 2 & 1 & 2 & 4 & 3 & 3 & 1 & 1 & 4 & 1.29 \\
\hline 年 & 10 & 1 & 3 & 1 & 1 & 3 & 3 & 4 & 4 & 5 & 5 & 2 & 2 & 4 & 4 & 0.29 \\
\hline 群 & 11 & 5 & 4 & 4 & 3 & 5 & 2 & 2 & 5 & 3 & 5 & 1 & 4 & 2 & 1 & 2.00 \\
\hline \multicolumn{2}{|c|}{ RMS } & \multicolumn{2}{|c|}{1.09} & \multicolumn{2}{|c|}{1.45} & \multicolumn{2}{|c|}{1.09} & \multicolumn{2}{|c|}{1.09} & \multicolumn{2}{|c|}{0.64} & \multicolumn{2}{|c|}{1.18} & \multicolumn{2}{|c|}{1.27} & \\
\hline
\end{tabular}

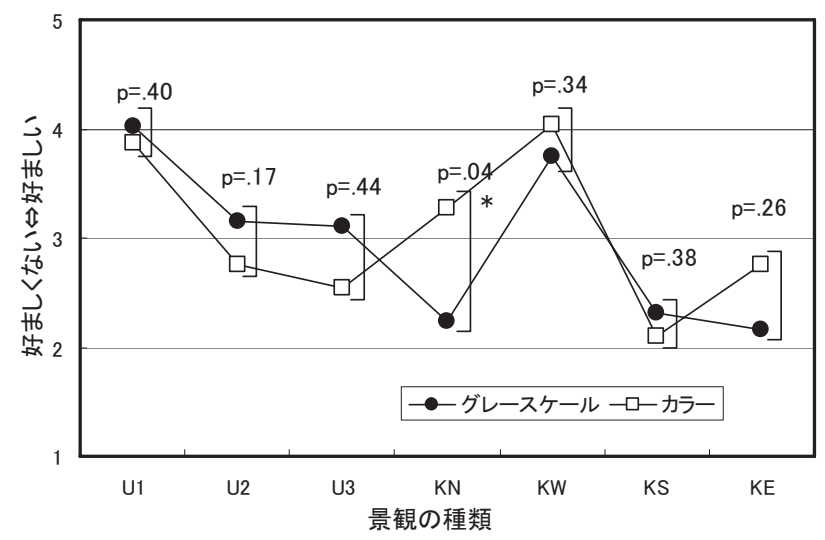

図 3 各エレメントの呈示画像の色彩状況別ランク平均值 （被験者の年齢を区分しない平均値）

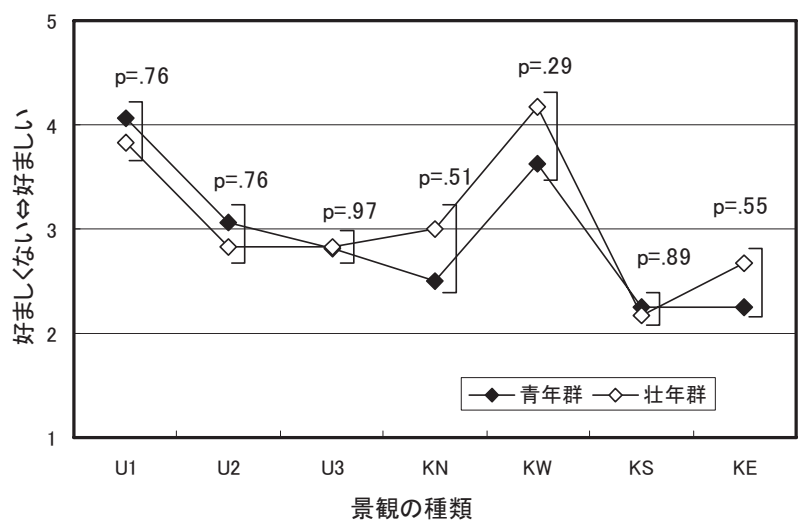

図 4 各エレメントの呈示画像の世代別ランク平均值 (カラー、グレースケールを区分しない平均值)
いえる。目立つ建築物や植樹帯などの状況はグレースケールであっ ても色の状態が想像しやすいものであり、色が加わったことによる イメージの変化が少なかったのではないかと考えられる。
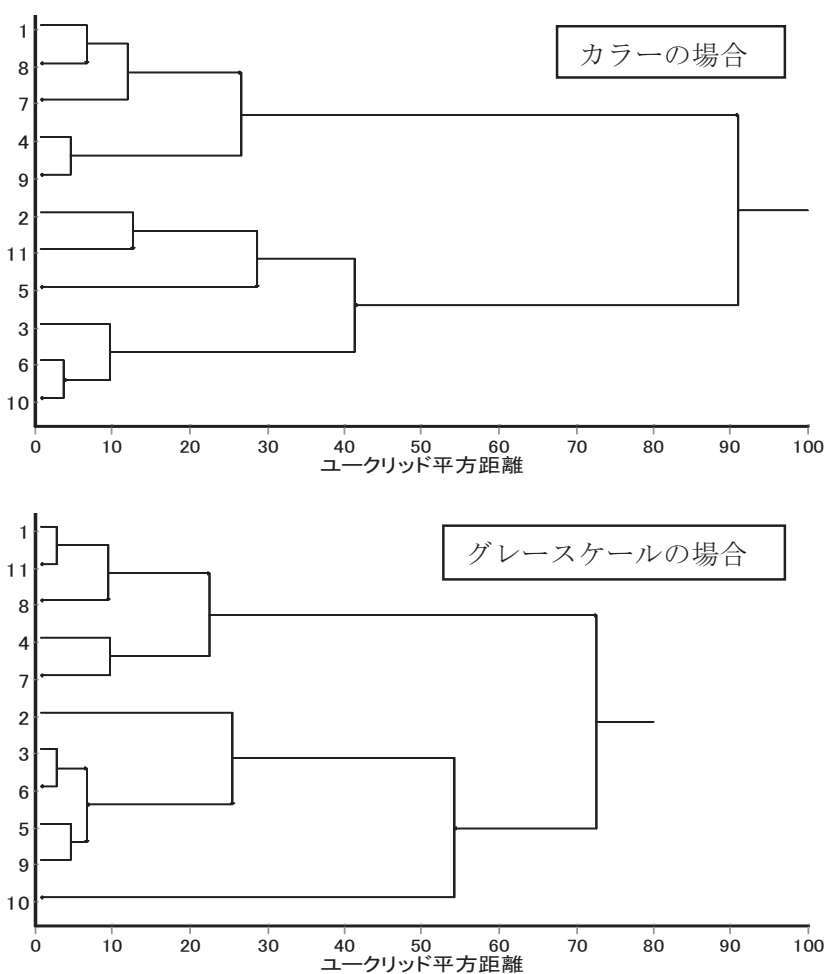

図 5 好ましさ評価に基づいたクラスター分析のデンドログラム 左側の数值は被験者番号（1 8: 青年群、9 11 : 壮年群)

\section{2 評価傾向の推定について}

クラスター分析の結果に基づいて、被験者をグループ化してその 特徴について検証する。グレーもカラーも基本的には同じような評 価語が得られているが、カラーの方がより現実を投影し、得られる イメージも多様であることから、カラーの結果を用いて検証する。

表 4 はカラー画像を用いた場合の景観の好ましさと評価語の関連 を示したものである。本来はラダーリングの評価語だけから具体的 条件を定めたいところであるが、実際に被験者の言いたいことは特 定のエレメントの景観を反映している。様々な環境状態が暗黙の背 景として存在しているのである。そのため、評価語だけを見るので はなく、エレメントも同時に見て実験者が現象学的に実験者の心理 を理解することで、より明確に全体構造を明らかにできる。現象学 的な理解という点では個人ごとの解釈が基本である。クラスターに 分けることは、評価の傾向のタイプを類型化して概要をとらえやす くするためである。

これらのことから、クラスターごとに好ましいと感じる景観にお ける特徴は以下のような点ではないかと推定できる。

\section{(1)伝統的町並みとして (U1,U2,U3)}

クラスターA,B の基本的な好ましさの判断は伝統的な家並みで あると考えられる。自然と建物のバランスがよく、景観が整っ ていると感じている

(2)田園的景観として（KN,KS,KW）

クラスター $\mathrm{C}$ の基本的な好ましさの判断は、田園が広がった空 
間であると考えられる。田んぼがあることでゆったりとして、 見晴らしがよく、景観が整っていると感じている。

(3)構造が分かりやすい (KN,KW)

クラスターD は道路、河川、海、山といった景観構成が分かり や寸い場所を好んでいる。メリハリのある空間が相対的に高い 評価となっている。

(4)都市性が豊か (KE, KW)

クラスター $\mathrm{E}$ は、都会的な䨌囲気を感じられる点に好ましさを 感じている。KW は画面左には田園的景観が見えるが、右手前 に並木のある直線道路があり、その奥に港があるということで 発展しつつある都市という雾囲気が感じられる景観となって いる。

その反面それぞれ好ましくないという判断がどこで生じているの かを推定すると以下のようなことが考えられる。

(1)伝統的町並みに現代的建築が混入している（U1,U2,U3）

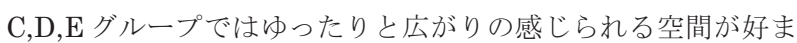
しいと感じている。そのため、このような空間は雑駁な印象に なっているのではないかと推定される。

(2)田園地帯に現代的建築が混入している (KN,KS)

$\mathrm{A}, \mathrm{B}$ グループに見られるように、田園がプラスの要素となって いないのは、都市としての景観と考えた場合に発展していない

表 4 各被験者クラスターの景観評価の好ましさと 評価語の関連（カラー画像）

\begin{tabular}{|c|c|c|c|}
\hline \multirow{2}{*}{$\begin{array}{l}\text { ク } \\
\text { ラ } \\
\text { 永 } \\
1\end{array}$} & \multirow{2}{*}{$\begin{array}{l}\text { 被 } \\
\text { 験 } \\
\text { 者 }\end{array}$} & 好ましい景観 & \multirow{2}{*}{$\begin{array}{c}\text { 評価の基本構造 } \\
\text { (景観状況と評価語からの推定) }\end{array}$} \\
\hline & & 好ましくない景観 & \\
\hline \multirow{2}{*}{ A } & 1 & U1 U3 & \multirow{2}{*}{$\begin{array}{l}\text { 自然と建物のバランスが良い } \\
\text { 古い伝統的な町並みの景観 } \\
\text { 田んぼが広がる景観(一) } \\
\text { 空地がある }(-)\end{array}$} \\
\hline & $\begin{array}{l}8 \\
7\end{array}$ & KN KW KS KE & \\
\hline \multirow{2}{*}{ B } & \multirow{2}{*}{$\begin{array}{l}4 \\
9\end{array}$} & U1 U2 KE & \multirow{2}{*}{$\begin{array}{l}\text { 景観が整っている } \\
\text { 色鮮やかな景観 } \\
\text { 田んぼが広がる景観 }(-) \\
\text { 駐車場が見える } \\
\text { 空地がある }(-)\end{array}$} \\
\hline & & U3 KN KW KS & \\
\hline \multirow{2}{*}{$\mathrm{C}$} & \multirow{2}{*}{$\begin{array}{c}2 \\
11\end{array}$} & KN KW KS & \multirow{2}{*}{$\begin{array}{l}\text { ゆったりしている } \\
\text { ごちゃごちゃしていない } \\
\text { 都会的 } \\
\text { 田んぼが広がる景観(+) }\end{array}$} \\
\hline & & U1 U3 KE & \\
\hline \multirow{2}{*}{ D } & \multirow{2}{*}{5} & U2 U3 KN KW & \multirow{2}{*}{$\begin{array}{l}\text { 自然と建物のバランスが良い } \\
\text { 車の色が鮮やか }\end{array}$} \\
\hline & & $\mathrm{U} 1 \mathrm{KS} \mathrm{KE}$ & \\
\hline \multirow{2}{*}{$\mathrm{E}$} & 3 & $\mathrm{KW}$ & \multirow{2}{*}{$\begin{array}{l}\text { 見晴らしが良い } \\
\text { 都会的 } \\
\text { 色鮮やかな景観 } \\
\text { にぎやかで活気がある }\end{array}$} \\
\hline & 10 & U2 & \\
\hline
\end{tabular}

枠で囲った景観は、クラスター内で最も好ましさ数 值が高かった（低かった）ものを示している
印象をもたらすためではないかと考えられる。また、使途の明 確でない空地や、広すぎる駐車場も、景観のバランスを崩す要 因になっていることが推定される。大型商業施設などの大きな 建築物とではスケール感の違いが大きすぎることでバランス が悪く感じる場合もあると考えられる。

以上を踏まえることで、各対象において考えられる景観対策とし ては以下のような例が考えられる。

伝統的町並みに住宅地が入り込んだ景観では、建築物が密集した 雑然とした印象になるので、景観を損なわないような形態の建物・ 屋根の色使いとするような対策が考えられる。どのような建物・屋 根の色使いがよいかについてはまた別の検討が必要となる。

田園地帯に住宅地が入り込んだ景観では、広さのある駐車場のよ うな場所が目立つので、駐車場やアスファルト舗装部分に植栽を加 えるといった対策が考えられる。

商工業地域では大型建築物が入り組んだ景観になるため、はっき りとした色使いにするといった都会的な印象を積極的に引き出す方 法が考えられる。また、反対に少しでも落ち着きを引き出すために 屋上・壁面緑化のような方法で緑を増やすことも考えられる。実際、 好ましさの個人差が大きいため、どちらもありえるといえる。

\section{5. まとめ}

本実験により、実験結果から直接明らかになったことをまとめる と以下の 3 つになる。

(1) 評価語の数とランク付けを指標としたクラスター分析か らは、カラー画像の方が多様なイメージを喚起しているこ とが判明した（3.1、4.1より）。

(2) 景観の評価傾向の差は、年齢に依存しない（3.3より）。

(3) 景観内の視対象の色彩状況が想像しや寸いものでは、エレ メントの色彩の有無による差異は小さい $(4.1$ より)。

また、景観評価の傾向としては、以下のような点が推定されるこ とを示した。

(4) 評価の際に着目される要素としては、樹林などの緑、建物 の新しさ(古さ)、建物の並び方など、まちなみの状況があ る(3.2より)。

(5) 基幹的構築物（電線・鉄塔・橋・道など）の状況を見るこ とで、その町の自然環境の状態、暮らしや寸さ（治安、利 便性、将来性など)、まちの䨌囲気（開放感、清潔感、落 ち着き、静けさなど）を感じ取っている（3.2より）。

(6) 好ましいと感じる俯瞰景観には、景観構造の明快さと、自 然の豊かさが関与している。伝統的町並みと住宅地の混在 や、田園地帯と住宅や商業施設などの混在は、統一感のな いごちゃごちゃとした印象になりやすい (4.2より)。

俯瞰された場合のまちづくりの要件としては、建物自体やその配 列だけでなく、緑の量的な割合や基幹的構築物のデザイン（色や大 きさ）などをコントロールするべきことなどが示された。

今後の課題としては、対象空間をさらに多様化することも望まれ る。今回実験で用いた対象は伝統的な住宅の混在する地域と、田園 地帯から開発される途上の地域であり、もう少し一般的な住宅街・ 商業的地区といった対象についても同様のことが言えるのかを検証 
する必要があると考えられる。

また、景観のコントロールとしてどのような手法が有効であるか を明らかにすることが、最終的な目的である俯瞰景観の保全のため には必要である。

\section{謝辞}

本研究の実施に当たっては山村真樹氏 (実験実施当時本学 4 年生) の協力が不可欠であった。記して謝意を表する次第である。

\section{参考文献}

1）川㠃寧史、土田義郎、下川雄一：金沢都心部における眺望景観の全体と部 分の印象評価, 日本建築学会環境系論文集, Vol. 73, No. 627, pp. 669-677, 2008. 5.

2）讃井純一郎、乾正雄 : 集合住宅外観の評価構造 個人差を考慮した断層的 重回帰分析、日本建築学会学術講演梗概集、D 環境工学、 pp. 645-646, 1986.

3) 土田義郎 : 知覚事象記録に基づく街路景観の認知構造分析 (大澤光編: 「印 象の工学」とは何か，丸善プラネット，2000）。

4) 奥敬一、深町加津枝: 嵐山の森林景観における地域らしさの評価構造，ラ ンドスケープ研究, Vol. 68, No. 5, pp. 747-752, 2005

5）松本邦彦、澤木昌典、柴田祐 : 大都市圈周縁部における農地を中心に構成 される景観の評価構造に関する研究，ランドスケープ研究，Vol.70, No. 5, pp. 555-558, 2007.

6) 長岡希、岡田準人、下村孝 : ビデオ画像を用いた屋上緑化の景観評価構造 の解析, 日本緑化工学会誌, Vol. 29, No. 1, pp. 113-118, 2003.

7）上野宏他 4 名：識別尺度の研究 1, 日本建築学会論文報告集号外, p. 500, 1966.

8) 高橋鷹志他 4 名: 識別尺度の研究 2 , 日本建築学会論文報告集号外, p. 501,1966

9）川崎寧史: 大気遠近を考慮した建築壁面要素の識別距離の算定, 日本建築 学会計画系論文集, No. 576, pp. 75-81，2004.2.

10）篠原修、樋口忠彦：自然地形と景観，土木学会第 26 回年次学術講演会梗 概集, IV, 1971.

11）天谷華子、山崎正史: 夜間眺望景観の構図論的考察，平成 12 年度都市計 画論文集, No. 35, pp.751-756, 2000.

12）クフィル・イスラエル・ジブ他 3 名 : 大阪湾人工島における住戸からの 眺望評価一住民の評価之居間からの景観写真に対する重回帰分析一, 日本 建築学会計画系論文集，No. 554，pp. 357-364，2002.4.

13）村川三郎、西名大作、横田幹朗：被験者実験による水際建築物からの眺 望に対する選好特性, 日本建築学会計画系論文集, No. 481, pp. 103-111, 1996. 3.

14）横田幹朗、村川三郎、西名大作 : 住民の撮影写真に基づく水際建築物か らの眺望景観の選好特性, 日本建築学会計画系論文集, No. 547, pp. 87-94, 2001.9.

15）横田幹朗他 3 名：水際建築物からの住民撮影眺望景観に対する非住民被 験者による選好特性の検討, 日本建築学会計画系論文集, No. 558 , pp. $79-86,2002.8$.

16）横田幹朗、村川三郎、西名大作、大場誠一郎：水際建築物からの眺望景 観の特性と被験者による心理的評価の関連, 日本建築学会計画系論文集, No. 573, pp. 79-85, 2003.11.

17）吉田誠他 3 名：超高層マンションからの眺望価值に関する研究，平成 9 年度都市計画論文集, No. 32, pp. 487-492, 1997.

18）土田義郎、小酒祐貴 : 評価グリッド法支援ツールの開発と応用, 日本建築 学会技術報告集, Vol.14, No. 27, pp. 205-208, 2008.6.

19）北村眞行 : Let's Stat!（多変量解析シェアウエア、バージョン 040917), http://homepage3. nifty. com/QZM01222/ (2008/11/19 現在).

\section{注}

注 1）金沢市の景観に関する条例には以下のようなものがあり、まちの特徴 を考慮した施策が実施されている。(1) 金沢市における伝統環境の保存およ び美しい景観の形成に関する条例（昭和 43 年、平成元年改定）、(2) 金沢 市こまちな夕保存条例（平成 6 年）、（3）金沢市屋外広告物条例（平成 7 年）（景観保全型広告整備地区の規定がある）、（4）金沢市用水保全条例（平
成 8 年）（5) 金沢市斜面緑地保全条例（平成 9 年）、(6) 金沢の歴史的文化 資産である寺社等の風景の保全に関する条例（平成 14 年）、(7)金沢市に おける美しい沿道景観の形成に関する条例（平成 17 年）、(8) 金沢市にお ける夜間景観の形成に関寸る条例（平成 17 年）。これらは個別の建築物や 特殊な地域に対寸る条例 (9) 金沢市文化財保護条例 (昭和 48 年)、(10) 金沢 市伝統的建造物群保存地区保存条例 (昭和 52 年) と関与しつつ、まち全体の 魅力を保全・発展させることを意図している。

(2009年 1 月 10 日原稿受理, 2009 年 5 月11日採用決定) 